\title{
Prevalence and aetiology of cataract in Punjab
}

\author{
ARIN CHATTERJEE, ${ }^{1}$ ROY C. MILTON, ${ }^{2}$ AND SYDNEY THYLE ${ }^{1}$ \\ From the ${ }^{1}$ Department of Ophthalmology, Christian Medical College, Ludhiana, Punjab, India, and the \\ ${ }^{2}$ Office of Biometry and Epidemiology, National Eye Institute, National Institutes of Health, Bethesda, \\ Maryland USA
}

Summary Three districts in the Punjab plains were surveyed in 1976-7 for senile cataract and potential risk factors. The prevalence of senile cataract was $15 \cdot 3 \%$ among 1269 persons examined who were aged 30 and older, and $4.3 \%$ for all ages. These figures confirmed previous reports of high prevalence. The prevalence was $1 \%$ for ages 30-49 and increased markedly in the sixth and seventh decades to $67 \%$ for ages 70 and older. Univariate age-adjusted analyses of selected socioeconomic, demographic, dietary, and other variables suggested that a higher prevalence was associated with being widowed, low education, use of rock salt in cooking, infrequent consumption of various protein foods (beans and lentils, milk, eggs, and curd), short height, and low weight. Multivariate analysis further suggested low total protein consumption as a risk factor that may account for as much as $40 \%$ of the excess prevalence of Punjab cataract over that in a US population study.

Cataract is a major cause of blindness worldwide, especially in the tropical belt, where most of the densely populated developing countries are located. ${ }^{1}$ In India $40 \%$ of all blindness may be due to cataract ${ }^{2}$; 27 million persons are blind from cataract in one or both eyes, ${ }^{1}$ and the prevalence of cataract is about $7 \% .^{3}$ Most of these cataracts are unassociated with other eye diseases, and the resultant blindness is curable. Though hundreds of 'eye camps' and mobile eye clinics $^{45}$ are organised each year to serve the largely rural population, present levels of effort can restore vision to only a fraction of those blind and visually handicapped by cataract.

Surveys in different climatic zones in northern India have found cataract prevalence of $4-10 \%$, with senile cataract appearing and steadily increasing after age 30 and with prevalence 13-36\% among persons aged 30 and older. ${ }^{6-10}$ Variations in prevalence may be related to different environmental factors, but differences in cataract definition and field survey methodology are likely to account for much of the variation. Nevertheless, the reported high prevalence significantly exceeds that reported in the United State ${ }^{11}$ and other countries.

The aetiology of senile cataract remains obscure even though it is a common disease. In this study we verify a high prevalence area and attempt to identify factors related to the risk of developing senile Correspondence to Dr Arin Chatterjee, Christian Medical College, Ludhiana, Punjab 141008, India. cataract. In addition to general socioeconomic and demographic variables we also include nutrition, ${ }^{12}{ }^{13}$ fluoride $^{14}$ and other minerals in drinking water, genetics, and others, following suggestions in an earlier report. ${ }^{9}$

\section{Subjects and methods}

Census information was used to select 3 geographically identifiable districts in the green belt of the Punjab plains, of about 1500 population each, of which one-third were expected to be aged 30 or older; a section of Ludhiana city slums (fieldganj); a nearby village (Narangwal); and à more distant village in the region known for high fluoride content of household water (Bajakhana) (Fig. 1). Each district was mapped and its households and regular occupants enumerated and checked against the census lists.

Field work was done in 1976-7. Under the supervision of the principal investigator (AC) an ophthalmologist (ST) and an ophthalmic assistant visited each household during daylight hours and clement weather, and examined each member aged 30 or older who was present and willing to be examined. Absent members were examined when possible on repeated visits. Of 4762 persons enumerated $1529(32 \%)$ were aged 30 or older and $83 \%(1269)$ of them were examined (Table 1). The response to examination was $76 \%$ for men and $91 \%$ for women; $52.6 \%$ of examinees were women. 
Fig. 1 Study districts in Punjab: Fieldganj (Ludhiana), Narangwal, and Bajakhana.

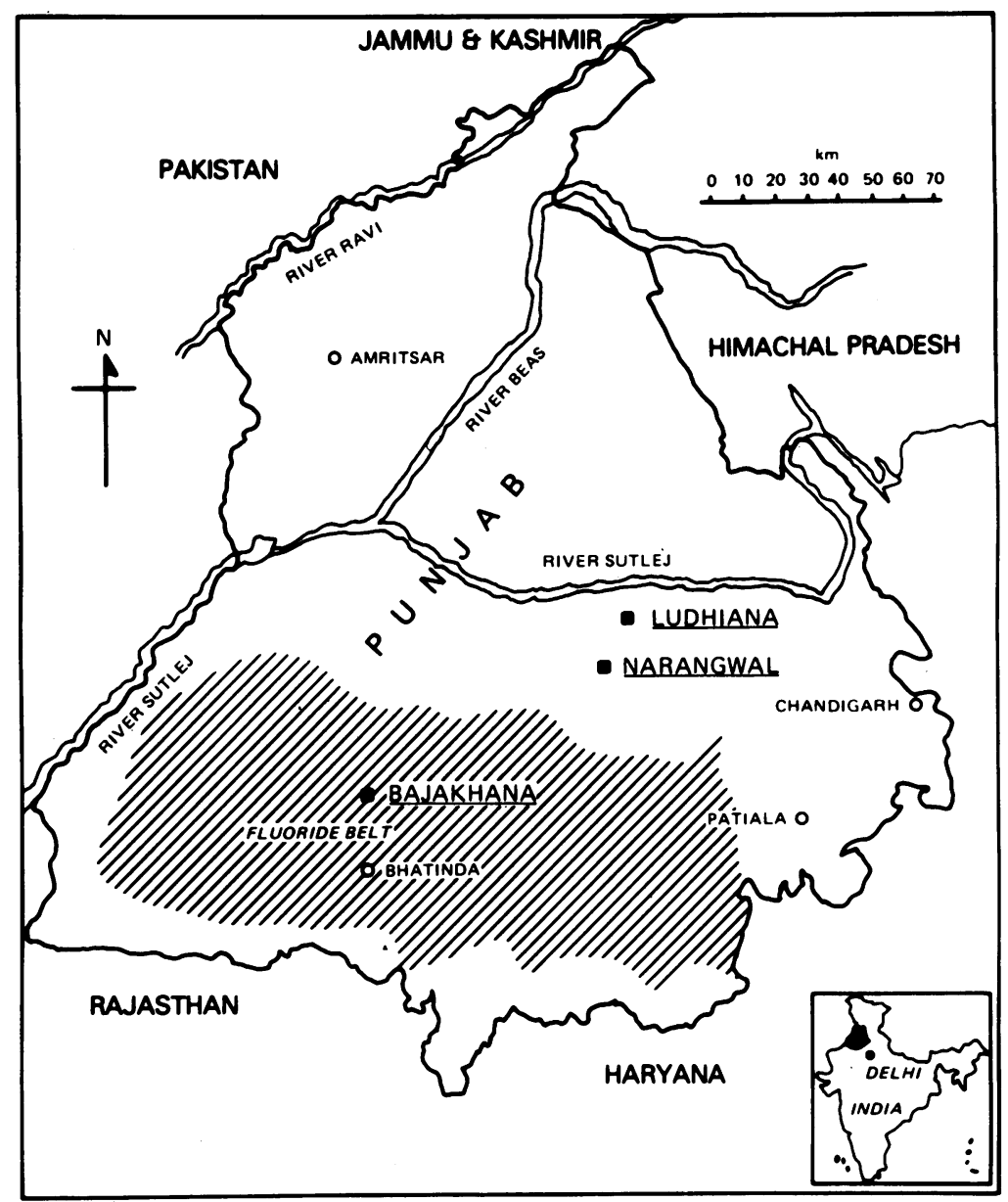

Examinations were performed according to a written protocol suitable for local field study conditions, and the results recorded on an examination form designed to facilitate coding for subsequent computer analysis. Responses to questionnaire items

Table 1 Study census* and percentage examined, by age and sex

\begin{tabular}{|c|c|c|c|c|c|c|}
\hline \multirow[b]{2}{*}{ Age (yrs) } & \multicolumn{2}{|l|}{ Male } & \multicolumn{2}{|l|}{ Female } & \multicolumn{2}{|l|}{ Total } \\
\hline & $\begin{array}{l}\text { No. in } \\
\text { census }\end{array}$ & $\begin{array}{l}\% \\
\text { Examined }\end{array}$ & $\begin{array}{l}\text { No. in } \\
\text { census }\end{array}$ & $\begin{array}{l}\% \\
\text { Examined }\end{array}$ & $\begin{array}{l}\text { No. in } \\
\text { census }\end{array}$ & $\begin{array}{l}\% \\
\text { Examined }\end{array}$ \\
\hline $30-39$ & 272 & 76 & 238 & 89 & 510 & 82 \\
\hline $40-49$ & 193 & 72 & 197 & 94 & 390 & 83 \\
\hline $50-59$ & 135 & 74 & 153 & 90 & 288 & 83 \\
\hline $60-69$ & 121 & 73 & 90 & 90 & 211 & 80 \\
\hline $70-79$ & 51 & 100 & 33 & 85 & 84 & 94 \\
\hline $80+$ & 24 & 83 & 22 & 95 & 46 & 89 \\
\hline Total & 796 & 76 & 733 & 91 & 1529 & 83 \\
\hline
\end{tabular}

*Number enumerated under age 30: 3233.
(Table 2) were recoded in appropriately defined categories. Visual acuity was tested with a Snellen illiterate $E$ chart, held in the shade of a building so that it was not directly illuminated by sunlight, at a distance marked by a 6 metre rope. Acuity was recorded separately for each eye, the examinee occluding the other eye and taking care not to press on the eye. Acuity was tested with spectacles when available, and in all eyes with acuity less than $6 / 6$ was further checked with plus and minus spherical lenses of power 1,2,3, and 4. Pinhole acuity was also tested for eyes with acuity less than $6 / 6$. The best vision thus obtained was recorded.

Lens examination was done in a dimly illuminated room in the examinee's house both with a uniocular loupe with oblique focal illumination and with distant direct ophthalmoscopy through an undilated pupil. Lens opacity location, form, and type were recorded according to the examination protocol. Opacities not of diabetic, traumatic, congenital, mixed, or other 
Table 2 Questionnaire items

\begin{tabular}{l} 
Age \\
Caste \\
Marital status \\
Economic status \\
Education \\
Usual occupation in last 10 years \\
Occupation location (indoors or out) \\
Cigarette smoking \\
Alcohol intoxication \\
'Usually urinate at night?' \\
'Sugar disease?' \\
Diet history: corn bread, wheat bread, beans and lentils, rice, meat, \\
milk, eggs, curd, vegetables \\
Type of curd eaten \\
Use, type of salt \\
Water source \\
Weight \\
Height \\
\hline
\end{tabular}

type were designated senile type and further graded as to maturity.

Samples of drinking water were collected at random locations in each of the 3 districts and analysed for fluoride $(\mathrm{F})$ by the colorimetric or visual comparison method at Patiala Medical College; for sodium (Na) and potassium $(\mathrm{K})$ by flame photometry and calcium (Ca) by atomic absorption spectrophotometry, at the Department of Biochemistry, Christian Medical College Hospital, Ludhiana; and for magnesium (Mg by the versenate titration method at Punjab Agricultural University.

For prevalence and analysis of associations we used as a 'case' a person with aphakia not attributable by history or examination to specific causes, or an opacity of senile type accompanied by best visual acuity $6 / 18$ or worse, in at least one eye. Prevalence is based on persons actually examined, with no adjustment for unexamined eligible persons. Association of single polychotomous variables with cataract was assessed by direct adjustment of prevalence to 10 year age groups of the total study population, and by the Mantel-Haenszel ${ }^{15}$ significance test of 'average' relative odds comparing different levels of a variable. Note that the adjusted rates are valid for comparisons only within this study or in populations with similar age distribution.

The multiple logistic function, ${ }^{16}{ }^{17} \mathrm{p}=\left(1+\mathrm{e}^{-\mathrm{y}}\right)^{-1}$ where $Y=a+\Sigma b_{i} X_{i}$, was used to examine multivariate association with senile cataract or aphakia. In this model $p$ is the probability or risk of senile cataract or aphakia, the $\mathrm{X}_{\mathrm{i}} \mathrm{s}$ are values of individual risk factors or variables (either discrete or continuous), and the $b_{i} s$ are coefficients to be estimated from the data. Positive coefficients indicate factors that increase risk. Maximum likelihood estimates of the coefficients were obtained by iteratively reweighted least squares. ${ }^{17}$ Variables were selected for inclusion in the model from among those showing the strongest univariate associations, and were retained in the model if their contribution to association was significant and if they were not highly correlated with other variables in the model.

\section{Results}

Lens examination findings are summarised by location and type of opacity and gradation of senile cataract in Table 3. Opacities were found in $14 \%$ of the eyes of persons age 30 and older. Aphakia was unilateral in 30 persons and bilateral in 26 persons. Three-quarters of the senile cataracts were early immature (iris shadow present and some fundal detail visible by direct ophthalmoscopy).

Table 4 shows the prevalance of senile cataract accompanied by best visual acuity $6 / 18$ or worse, or aphakia, by age and sex. Overall prevalence was $15.3 \%$ for ages 30 and older, and $4.3 \%$ for all ages assuming negligible occurrence under age 30. Bilateral senile cataract or aphakia occurred in $73 \%$

Table 3 Lens examination of persons age 30 and older

\begin{tabular}{|c|c|c|}
\hline & $\begin{array}{l}\text { Number } \\
\text { of eyes }\end{array}$ & $\%$ \\
\hline \multicolumn{3}{|l|}{ Lens opacity location: } \\
\hline No opacity, or aphakia & 2161 & $85 \cdot 1$ \\
\hline Anterior cortex & 5 & $0 \cdot 2$ \\
\hline Nucleus & 151 & $6 \cdot 0$ \\
\hline Posterior cortex & 52 & $2 \cdot 1$ \\
\hline Posterior subcapsular & 8 & $0 \cdot 3$ \\
\hline Mixed & 73 & $2 \cdot 9$ \\
\hline Other & 67 & $2 \cdot 6$ \\
\hline Not done* & 21 & $0 \cdot 8$ \\
\hline Total & 2538 & $100 \cdot 0$ \\
\hline \multicolumn{3}{|l|}{ Lens opacity type: } \\
\hline No opacity & 2078 & 81.9 \\
\hline Aphakiat & 83 & $3 \cdot 3$ \\
\hline Diabetic type & 0 & — \\
\hline Traumatic & 1 & $0 \cdot 0$ \\
\hline Congenital & 11 & 0.4 \\
\hline Complicated cataract & 4 & $0 \cdot 2$ \\
\hline Mixed & 2 & $0 \cdot 1$ \\
\hline Unknown & 3 & $0 \cdot 1$ \\
\hline Not done* & 21 & $0 \cdot 8$ \\
\hline Other (including senile) & 335 & $13 \cdot 2$ \\
\hline Total & 2538 & $100 \cdot 0$ \\
\hline \multicolumn{3}{|l|}{ Senile cataract or aphakia: } \\
\hline Aphakia (bilateral, 26 persons) & 82 & $19 \cdot 9$ \\
\hline \multicolumn{3}{|l|}{ Senile cataract } \\
\hline Early immature & 248 & $60 \cdot 0$ \\
\hline Advanced immature & 47 & $11 \cdot 4$ \\
\hline Mature & 30 & $7 \cdot 3$ \\
\hline Hypermature & 6 & 1.4 \\
\hline Total & 413 & $100 \cdot 0$ \\
\hline
\end{tabular}

*Includes 1 enucleation, 16 phthisis, 2 corneal leucoma, 2 'blind eyes.'

tIncludes one aphakia due to trauma. 
Table 4 Prevalence of senile cataract* or aphakia, by age and sex

\begin{tabular}{|c|c|c|c|c|c|c|}
\hline \multirow[b]{2}{*}{ Age (yr) } & \multirow[b]{2}{*}{ Sex } & \multirow[b]{2}{*}{$\begin{array}{l}\text { No. } \\
\text { examined }\end{array}$} & \multicolumn{3}{|c|}{$\begin{array}{l}\text { Number with senile cataract } \\
\text { or aphakia }\end{array}$} & \multirow{2}{*}{$\frac{\%}{\begin{array}{l}\text { Oneor } \\
\text { two eyes }\end{array}}$} \\
\hline & & & One eye & Two eyes & $\begin{array}{l}\text { One or } \\
\text { two eyes }\end{array}$ & \\
\hline \multirow[t]{3}{*}{$30-39$} & $\mathbf{M}$ & 205 & 0 & 0 & 0 & $0 \cdot 0$ \\
\hline & $\mathrm{F}$ & 214 & 0 & 1 & 1 & 0.5 \\
\hline & Total & 419 & 0 & 1 & 1 & $0 \cdot 2$ \\
\hline \multirow[t]{3}{*}{$40-49$} & $\mathbf{M}$ & 138 & 1 & 2 & 3 & $2 \cdot 2$ \\
\hline & F & 185 & 3 & 1 & 4 & $2 \cdot 2$ \\
\hline & Total & 323 & 4 & 3 & 7 & $2 \cdot 2$ \\
\hline \multirow[t]{3}{*}{$50-59$} & M & 100 & 6 & 5 & 11 & $11 \cdot 0$ \\
\hline & $\mathrm{F}$ & 138 & 14 & 10 & 24 & $17 \cdot 4$ \\
\hline & Total & 238 & 20 & 15 & 35 & $14 \cdot 7$ \\
\hline \multirow[t]{3}{*}{$60-69$} & $\mathbf{M}$ & 87 & 8 & 24 & 32 & $36 \cdot 8$ \\
\hline & $\mathrm{F}$ & 82 & 9 & 30 & 39 & $47 \cdot 6$ \\
\hline & Total & 169 & 17 & 54 & 71 & $42 \cdot 0$ \\
\hline \multirow[t]{3}{*}{$70-79$} & $\mathbf{M}$ & 51 & 3 & 24 & 27 & $52 \cdot 9$ \\
\hline & $\mathrm{F}$ & 28 & 3 & 14 & 17 & $60 \cdot 7$ \\
\hline & Total & 79 & 6 & 38 & 44 & $55 \cdot 7$ \\
\hline \multirow[t]{3}{*}{$80+$} & $\mathbf{M}$ & 20 & 2 & 16 & 18 & $90 \cdot 0$ \\
\hline & F & 21 & 3 & 15 & 18 & $85 \cdot 7$ \\
\hline & Total & 41 & 5 & 31 & 36 & $87 \cdot 8$ \\
\hline \multirow[t]{3}{*}{ Total } & $\mathbf{M}$ & 601 & 20 & 71 & 91 & $15 \cdot 1$ \\
\hline & F & 668 & 32 & 71 & 103 & $15 \cdot 4$ \\
\hline & Total & 1269 & 52 & 142 & 194 & $15 \cdot 3$ \\
\hline
\end{tabular}

${ }^{*}$ With best visual acuity $6 / 18$ or worse.

Table 5 Distribution of frequency of use of food, according to response to interview, in percent

\begin{tabular}{lcccc}
\hline \multirow{2}{*}{ Food } & \multicolumn{4}{c}{ Number of times used per month } \\
\cline { 2 - 5 } & 0 & $1-5$ & $8-20^{*}$ & $30-90^{+}$ \\
\hline Corn bread & $57 \cdot 4$ & $9 \cdot 7$ & $3 \cdot 2$ & $29 \cdot 7$ \\
Wheat bread & $0 \cdot 0$ & $0 \cdot 0$ & $0 \cdot 1$ & $99 \cdot 9$ \\
Beans and lentils & $0 \cdot 2$ & $1 \cdot 2$ & $11 \cdot 8$ & $87 \cdot 0$ \\
Rice & $76 \cdot 9$ & $17 \cdot 1$ & $4 \cdot 7$ & $1 \cdot 3$ \\
Meat & $79 \cdot 0$ & $16 \cdot 1$ & $4 \cdot 0$ & $0 \cdot 9$ \\
Milk & $55 \cdot 6$ & $1 \cdot 3$ & $2 \cdot 3$ & $40 \cdot 8$ \\
Eggs & $82 \cdot 9$ & $7 \cdot 4$ & $6 \cdot 3$ & $3 \cdot 4$ \\
Curd & $54 \cdot 8$ & $5 \cdot 0$ & $9 \cdot 2$ & $31 \cdot 0$ \\
Vegetables & $12 \cdot 8$ & $0 \cdot 0$ & $0 \cdot 7$ & $86 \cdot 5$ \\
\hline
\end{tabular}

*Two to 5 times per week.

tOne to 3 times per day.

of the 194 cases. Prevalence increased steadily with age, with marked increases seen in the sixth and seventh decade. Age-adjusted prevalence was $13.7 \%$ for men and $\mathbf{1 6 . 9 \%}$ for women aged 30 and older. This difference is of marginal significance $(p=0.07)$ and size of effect (combined relative odds $=1 \cdot 5$ ). The lower rate of response to examination by men, together with the possibility that men away from home and working have less cataract than those at home, suggests the likelihood of a more definite sex difference in prevalence. Nevertheless, adjustment for sex was not done in subsequent analyses of association with single variables. Aphakia accounted for $24 \%$ of all eyes with cataract or aphakia in Table 4 .

Table 5 shows the distribution of frequency of use of foods according to questionnaire response. Wheat bread, beans and lentils, and vegetables were each reported as eaten at least once a day by over $85 \%$ of the study population. Rice, eggs, and meat were each reported as never eaten by over $75 \%$ of the respondents. Analysis of association of food use with senile cataract was based on approximate tertiles of frequency of use.

Age-adjusted percentage cataract or aphakia is given in Table 6 for each level of selected questionnaire items, along with results of continuity-corrected Mantel-Haenszel significance tests of differences between levels. Age-adjusted prevalence for urban Fieldganj $(18.5 \%)$ was higher than for either rural district, $13.8 \%$ and $13.6 \%(p<0.04)$. Khatri and Arora caste members showed significantly higher prevalence than for the Jath caste $(\mathrm{p}<0 \cdot 03)$. Adjusted prevalence for widowed persons was higher than for married persons $(p=0 \cdot 001)$. Prevalence decreased as economic status improved, and was significantly lower for high school graduates than for illiterates $(p<0 \cdot 03)$. Usual occupation, location of occupation, cigarette smoking, and alcohol intoxication were applicable to men only, with no significant findings but with the suggestion of higher prevalence for indoor occupations, nonsmokers, and nondrinkers.

Affirmative response to 'Usually urinate at night?' and 'Sugar disease?', possibly indicative of diabetes, had higher prevalence of cataract or aphakia (although not significantly so) than negative response.

Among the dietary variables higher prevalence was associated with infrequent consumption of beans and lentils $(p<0.005)$, meat $(p<0.06)$, milk $(p<0.04)$, eggs $(p<0.03)$, and curd (or yoghourt) $(p<0.02)$. For curd made from buffalo milk, prevalence was higher for skim milk curd than for whole milk curd $(p=0.05)$; use of curd from cow's milk was rare. Prevalence was higher among persons using rock salt in cooking than among persons never using rock salt $(\mathrm{p}<0 \cdot 01)$.

Higher prevalence of cataract or aphakia was associated with short height $(p<0.05)$, with low weight $(p<0.02)$, and with low weight/height ratio $(\mathrm{p}<0.03)$.

Analysis of mineral content of drinking water showed no differences among districts in mean calcium, potassium, and magnesium. The 2 rural districts have over 3 times $(12 \mathrm{mEq} / \mathrm{l})$ the sodium found in Fieldganj water. Average fluoride in Bajakhana $(0.33 \mathrm{mEq} / \mathrm{l}$, or $6.2 \mathrm{ppm})$ is markedly elevated as expected, 10 or more times that of either of the other districts.

Preliminary multivariate analyses, which included most of the variables showing significant or consistent 
Table 6 Age-adjusted percentage senile cataract or aphakia, by levels of single study variables

\begin{tabular}{|c|c|c|c|c|c|c|c|c|}
\hline & $n^{\dagger}$ & $\%$ & & $n$ & $\%$ & & $n$ & $\%$ \\
\hline \multicolumn{3}{|l|}{ District: } & \multicolumn{3}{|c|}{ Usually urinate at night: } & \multicolumn{3}{|c|}{ Type of buffalo milk curd: } \\
\hline Fieldganj & 423 & $18 \cdot 5$ & Yes & 36 & $32 \cdot 7$ & No curd eaten & 697 & $16 \cdot 1$ \\
\hline Narangwal & 427 & $13 \cdot 8$ & No & 1233 & -14.9 & Home-made & 505 & $13 \cdot 0$ \\
\hline Bajakhana & 419 & $13 \cdot 6$ & \multicolumn{3}{|c|}{ Sugar disease: } & Fortified & 67 & $21 \cdot 2$ \\
\hline \multicolumn{3}{|c|}{$\begin{array}{l}{ }^{*} \text { Fieldganj }>\text { Narangwal, Bajakhana } \\
\mathrm{p}<0 \cdot 04 \mathrm{RO}=1 \cdot 78\end{array}$} & $\begin{array}{l}\text { Yes } \\
\text { No }\end{array}$ & $\begin{array}{r}9 \\
1255\end{array}$ & $\begin{array}{l}21 \cdot 6 \\
15 \cdot 2\end{array}$ & \multicolumn{3}{|c|}{${ }^{*}$ Fortified $>$ Home-made $p=0.05$} \\
\hline \multicolumn{3}{|c|}{ Caste: } & \multicolumn{3}{|c|}{ Corn bread, frequency per month: } & \multicolumn{3}{|c|}{ Vegetables, frequency per month: } \\
\hline Khatri & 80 & $19 \cdot 9$ & None & 728 & 15.9 & None & 162 & $17 \cdot 7$ \\
\hline Arora & 296 & $18 \cdot 3$ & $1-20$ & 164 & $16 \cdot 6$ & $1-30$ & 833 & $13 \cdot 7$ \\
\hline Bania & 52 & $16 \cdot 8$ & $21-90$ & 377 & $14 \cdot 2$ & $31-120$ & 274 & $18 \cdot 8$ \\
\hline Harijan & 344 & $14 \cdot 5$ & \multicolumn{3}{|c|}{ Wheat bread, frequency per month: } & \multicolumn{3}{|c|}{${ }^{*} 31-120>1-30 p=0.01 \mathrm{RO}=1.81$} \\
\hline Ramagharia & 61 & $14 \cdot 1$ & $8-30$ & 22 & $11 \cdot 3$ & \multicolumn{3}{|c|}{ Use of salt in cooking: } \\
\hline Jath & 393 & $13 \cdot 1$ & $31-60$ & 648 & $14 \cdot 6$ & Little & 21 & $11 \cdot 7$ \\
\hline Brahmin & 21 & $8 \cdot 3$ & $61-90$ & 599 & 15.9 & Average & 1238 & $15 \cdot 6$ \\
\hline Rajput & 19 & 3.9 & \multicolumn{3}{|c|}{ Beans and lentils, frequency per month: } & Much & 10 & $0 \cdot 0$ \\
\hline \multicolumn{3}{|c|}{${ }^{*}$ Khatri, Arora $>$ Jath $\quad p<0.03$} & $0-20$ & 165 & $21 \cdot 1$ & \multicolumn{3}{|l|}{ Use of rock salt: } \\
\hline $\mathrm{RO}=2 \cdot 99,1 \cdot 86$ & & & $21-30$ & 1055 & $14 \cdot 3$ & Never used & 934 & $13 \cdot 8$ \\
\hline \multicolumn{3}{|l|}{ Marital status: } & $31-90$ & 49 & $16 \cdot 5$ & Some use & 335 & $18 \cdot 9$ \\
\hline Single & 29 & $25 \cdot 2$ & ${ }^{*} 0-20>$ & $<0.005$ & $O=2 \cdot 29$ & ${ }^{*}$ Some use $>\mathrm{Ne}$ & er used & .01 \\
\hline Widowed & 138 & $22 \cdot 2$ & Rice, frec & mont & & $\mathrm{RO}=1.80$ & & \\
\hline Married & 1099 & $13 \cdot 9$ & None & 976 & $15 \cdot 1$ & Height, in $\mathrm{cm}$ : & & \\
\hline${ }^{*}$ Widowed $>$ Marn & rried $p=$ & & 1 & 112 & $17 \cdot 0$ & $101-152$ & 344 & $18 \cdot 4$ \\
\hline $\mathrm{RO}=2 \cdot 21$ & & & $2-30$ & 181 & $14 \cdot 3$ & $153-160$ & 359 & $15 \cdot 7$ \\
\hline Economic status: & & & Meat, fre & r mon & & $161-166$ & 259 & $11 \cdot 4$ \\
\hline Poor & 488 & $16 \cdot 8$ & None & 1002 & $15 \cdot 6$ & $167-185$ & 307 & $13 \cdot 7$ \\
\hline Low middle & 667 & $14 \cdot 9$ & $1-2$ & 136 & $16 \cdot 7$ & - & & \\
\hline Upper middle & 114 & $11 \cdot 8$ & $3-30$ & 131 & $9 \cdot 3$ & $101-160$ & 703 & $17 \cdot 3$ \\
\hline Education: & & & *None & $0.06 \mathrm{~F}$ & $=2 \cdot 13$ & $161-185$ & 566 & $12 \cdot 6$ \\
\hline Illiterate & 908 & $16 \cdot 2$ & Milk, frec & mon & & ${ }^{*} 101-152>161$ & 166,16 & $5 p<0.05$ \\
\hline Can read & 276 & $13 \cdot 7$ & None & 706 & $16 \cdot 7$ & $\mathrm{RO}=2 \cdot 39,1 \cdot 87$ & & \\
\hline Highschool grad & 85 & $4 \cdot 2$ & $1-20$ & 46 & $19 \cdot 2$ & ${ }^{*} 101-160>161$ & $185 p<$ & \\
\hline${ }^{*}$ Illiterate $>$ High & school & $p<0.03$ & $21-90$ & 517 & $13 \cdot 1$ & $\mathrm{RO}=1.81$ & & \\
\hline $\mathrm{RO}=7 \cdot 46$ & & & - & & & Weight, in kg: & & \\
\hline Usual occupation ( & men): & & $1+$ & 563 & 13.6 & $23-45$ & 401 & $18 \cdot 7$ \\
\hline Other & 156 & $17 \cdot 3$ & ${ }^{*}$ None & $<0.04$ & $D=1.57$ & $46-52$ & 293 & $15 \cdot 2$ \\
\hline Farmer & 102 & $15 \cdot 6$ & ${ }^{*}$ None & $07 \mathrm{RC}$ & $1 \cdot 48$ & $53-60$ & 269 & $12 \cdot 4$ \\
\hline Artisan & 26 & $15 \cdot 0$ & Eggs, frec & $\mathrm{r}$ mon & & $61-99$ & 306 & $11 \cdot 7$ \\
\hline Business & 124 & $11 \cdot 0$ & None & 1052 & $15 \cdot 7$ & - & & \\
\hline Laborer & 148 & $9 \cdot 2$ & $1-5$ & 94 & $15 \cdot 0$ & $23-52$ & 694 & $17 \cdot 2$ \\
\hline Professional & 44 & $3 \cdot 7$ & $6-60$ & 123 & 7.9 & $53-99$ & 575 & $12 \cdot 1$ \\
\hline Occupation location & in (men & & ${ }^{*}$ None & $0.03 \mathrm{~F}$ & $=2 \cdot 39$ & $* 23-45>53-60$ & 61-99 & \\
\hline Indoor & 288 & $17 \cdot 1$ & Curd, fre & $r$ mon & & $\mathrm{RO}=2 \cdot 01,2 \cdot 50$ & & \\
\hline Outdoor & 267 & $12 \cdot 5$ & None & 696 & $16 \cdot 1$ & ${ }^{*} 23-52>53-99$ & $0<0.00$ & $=1.88$ \\
\hline Mixed & 46 & $11 \cdot 5$ & $1-20$ & 180 & $18 \cdot 0$ & (Weight/Height) & 1000: & \\
\hline Cigarettes per day ( & (men): & & $21-90$ & 393 & $12 \cdot 1$ & $163-283$ & 330 & $17 \cdot 1$ \\
\hline None & 533 & $15 \cdot 2$ & - & & & 284-323 & 317 & $16 \cdot 9$ \\
\hline$<10$ & 28 & $9 \cdot 2$ & $0-20$ & 876 & $16 \cdot 1$ & $324-369$ & 305 & $14 \cdot 0$ \\
\hline $10-19$ & 23 & $5 \cdot 5$ & ${ }^{*}$ None, & $-90 p$ & .04 & $370-615$ & 317 & $12 \cdot 7$ \\
\hline $20+$ & 17 & $10 \cdot 4$ & $\mathrm{RO}=1$ & & & - & & \\
\hline- & & & ${ }^{*} 0-20>$ & $0.02 \mathrm{~F}$ & $=1 \cdot 81$ & $163-323$ & 647 & $16 \cdot 9$ \\
\hline $1+$ & 68 & $11 \cdot 4$ & & & & $324-615$ & 622 & $13 \cdot 1$ \\
\hline Alcohol intoxicatior & on (men & & & & & ${ }^{*} 163-283,284$ & $323>37$ & $5 p<0.07$ \\
\hline Do not drink & 262 & $17 \cdot 2$ & & & & $\mathrm{RO}=1 \cdot 79,1 \cdot 84$ & & 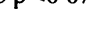 \\
\hline Never/rarely & 235 & $13 \cdot 2$ & & & & ${ }^{*} 163-323>324$ & $615 p<$ & \\
\hline $1 /$ month & 48 & $11 \cdot 9$ & & & & $\mathrm{RO}=1.61$ & 然 & \\
\hline 1/week & 56 & $12 \cdot 4$ & & & & & & \\
\hline$\overline{\text { Any drinking }}$ & 339 & $12 \cdot 9$ & & & & & & \\
\hline
\end{tabular}

*Significant differences; RO is relative odds by Mantel-Haenszel method.

†Number of persons at this level of the variable. 
Table 7 Multivariate risk function analysis, with risk factor coefficients ranked by $t$ values

\begin{tabular}{|c|c|c|c|}
\hline Risk factor & $\begin{array}{l}\text { Coeff. } \\
B\end{array}$ & $\begin{array}{l}\text { Std. } \\
\text { coeff. }{ }^{\dagger}\end{array}$ & $t$ \\
\hline \multicolumn{4}{|l|}{ Model 1: } \\
\hline Age & $0 \cdot 1366$ & 1.549 & 13.58 \\
\hline 'Nutrition' & -0.0114 & $-0 \cdot 341$ & $-2 \cdot 88$ \\
\hline Married* & $-0 \cdot 7050$ & $-0 \cdot 228$ & $-2 \cdot 88$ \\
\hline Weight & $-0 \cdot 0250$ & $-0 \cdot 283$ & $-2 \cdot 56$ \\
\hline 'Urinate at night'* & $1 \cdot 1305$ & $0 \cdot 185$ & $2 \cdot 31$ \\
\hline High school graduate ${ }^{*}$ & -1.5461 & $-0 \cdot 385$ & $-1 \cdot 70$ \\
\hline Constant & $-7 \cdot 9571$ & & $-9 \cdot 25$ \\
\hline \multicolumn{4}{|l|}{ Model 2: } \\
\hline Age & $0 \cdot 1411$ & 1.600 & 15.06 \\
\hline Constant & $-9 \cdot 4648$ & & $-16 \cdot 68$ \\
\hline
\end{tabular}

*Yes $=1, \mathrm{No}=0$.

+ Standardised coefficient for variable $\mathrm{X}=\mathrm{B} \times \mathrm{SD}(\mathrm{X})$, the contribution to change in $\log (p /(1-p))$ for one standard deviation change in $x$.

univariate associations in Table 6, were used to select a subset of variables likely to contribute meaningfully to multivariate association with senile cataract or aphakia. A general nutrition variable was created as the total frequency of use of protein foods: beans, meat, milk, eggs, and curd. Table 7 shows the results of multiple logistic regression analysis of association of risk of senile cataract or aphakia with age, education (high school graduate), 'Frequently urinate at night?', weight, marital status (married), and 'nutrition' as defined above (model 1), and also with

Table 8 Distribution of senile cataract or aphakia by decile of risk from multivariate risk function

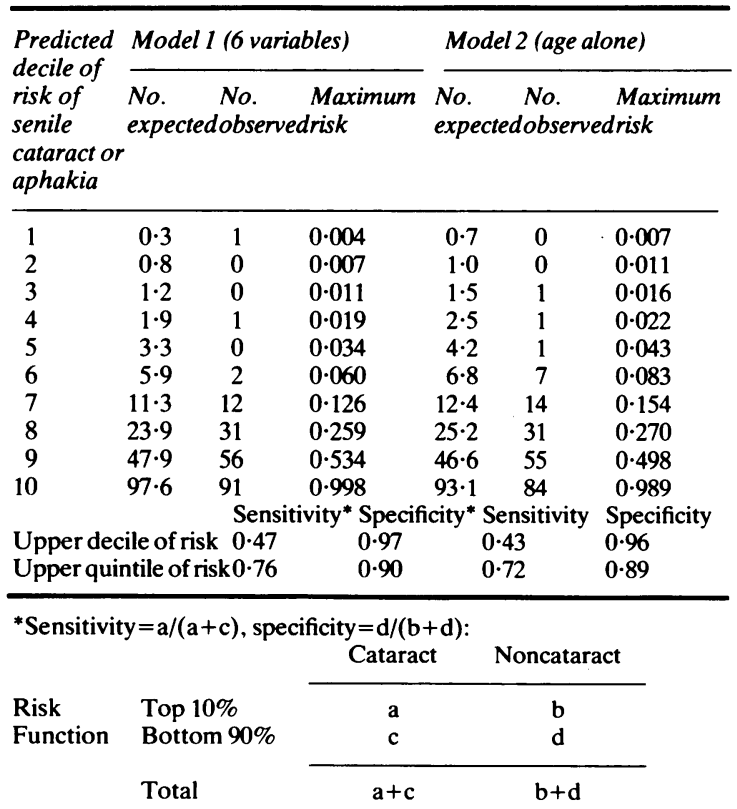

age alone (model 2). The number of expected and observed cases of senile cataract or aphakia is given by decile of risk in Table 8 , indicating the adequacy of fit of the multiple logistic model to the data.

Age alone was seen to be a good predictor of risk, with sensitivity $43 \%$, and $72 \%$ for the upper decile and quintile of risk, respectively. The 6-variable model improves slightly the prediction ability, but with statistically significant contributions from all variables except possibly high school graduate, yielding corresponding sensitivities $47 \%$ and $76 \%$. Risk decreases with increased 'nutrition', increased weight, for married persons, and for high school graduates. Risk increases with increasing age and for persons who frequently urinate at night. The relative odds (or relative 'risk') for one unit change in $X_{i}$, with

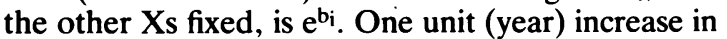
age is equivalent in relative risk to a decrease of 12 units in frequency of use of the foods in 'nutrition' and to $5.5 \mathrm{~kg}$ decrease in weight. The state of being married has relative risk equal to that of a decrease of 5 years of age. High school graduate status has relative risk equal to a decrease of 11 years of age. Similarly, frequent urination at night has relative risk equal to an increase of 8 years of age. Relative risk associated with an increase in age of $1,5,10,20$ years is $1 \cdot 15,1 \cdot 98,3 \cdot 92$, and $15 \cdot 4$, respectively.

\section{Discussion}

Prevalence of senile cataract in this study confirms the previously reported high rates for northern India. The age-adjusted prevalence comparable to the Framingham Eye Study is $43.3 \%$, almost 3 times higher than observed in Framingham (Table 9). This difference is conservative, since our acuity criterion was more stringent, our method of examination (in field conditions, with loupe and ophthalmoscope through undilated pupils) might be expected to yield some false negatives, and lesser opacities detectable by slit-lamp were included in the Framingham study. The Punjab prevalence is consistent with Framingham prevalance about 14 years later in age. Average life expectancy in Punjab (about 65 years) is one of the highest in India and only 6 years less than in Framingham. The mortality rate for all ages is $7 \cdot 9 / 1000$ in Framingham and about $11 \cdot 1 / 1000$ in our rural-urban Punjab population. Age-specific mortality for Punjab and Framingham do not differ greatly for ages 40 and older (Table 10). These similarities, together with lack of reason or evidence for lower mortality with cataract in Punjab, suggests that the markedly higher prevalence in Punjab is due to factors other than differences in aging. There is at present no basis for assessing whether genetic difference is an important factor. 
Table 9 Prevalence of senile cataract or aphakia for Punjab and Framingham, by sex and Framingham age groups*

\begin{tabular}{llll}
\hline Age $(y r)$ & Sex & $\begin{array}{l}\text { Punjab } \\
\%\end{array}$ & $\begin{array}{l}\text { Framingham } \\
\%\end{array}$ \\
\hline $52-64$ & $\mathrm{M}$ & $26 \cdot 2$ & $4 \cdot 3$ \\
& $\mathrm{~F}$ & $32 \cdot 7$ & $4 \cdot 7$ \\
& Total & $29 \cdot 4$ & $4 \cdot 5$ \\
$65-74$ & $\mathrm{M}$ & $35 \cdot 7$ & $16 \cdot 0$ \\
& $\mathrm{~F}$ & $52 \cdot 6$ & $19 \cdot 3$ \\
$75-85$ & Total & $43 \cdot 3$ & $18 \cdot 0$ \\
& $\mathrm{M}$ & $79 \cdot 3$ & $40 \cdot 9$ \\
& $\mathrm{~F}$ & $84 \cdot 6$ & $48 \cdot 9$ \\
Total & Total & $81 \cdot 8$ & $45 \cdot 9$ \\
& $\mathrm{M}$ & $36 \cdot 2$ & $13 \cdot 2$ \\
& $\mathrm{~F}$ & $45 \cdot 4$ & $17 \cdot 1$ \\
Total, age-sex & Total & $40 \cdot 5$ & $15 \cdot 5$ \\
adjusted to & & & \\
Framingham & & & \\
Eye & & & \\
Study & & & \\
population & & & \\
\hline
\end{tabular}

${ }^{*}$ Senile cataract definition includes best visual acuity $6 / 18$ or worse (Punjab), 6/9 or worse (Framingham).

When making many statistical comparisons at a given significance level (such as $p=0.05$ ), as was done for univariate risk factors, one is likely to find about one in 20 comparisons 'significant' even when in fact there are no real associations. We find about 25 significant associations at that level out of over 130, suggesting that some of them are likely to be real. Independent studies are required to verify these associations.

Univariate association of senile cataract or aphakia with caste is not readily distinguishable from association with Fieldganj district, since $95 \%$ of Arora and Khatri castes and $1 \%$ of Jath caste were in Fieldganj. Similarly, all users of skim milk curd and rock salt were in Fieldganj. Thus, the elevated prevalence in Fieldganj may reflect the effect of rock salt in cooking

Table 10 Age-specific annual mortality rates (per 1000) for Punjab and Framingham

\begin{tabular}{lcc}
\hline Age $(y r)$ & Punjab $^{*}$ & Framingham \\
\hline $40-44$ & $5 \cdot 3$ & $1 \cdot 2$ \\
$45-49$ & $5 \cdot 2$ & $3 \cdot 3$ \\
$50-54$ & $10 \cdot 8$ & $6 \cdot 9$ \\
$55-59$ & $11 \cdot 3$ & $11 \cdot 2$ \\
$60-64$ & $20 \cdot 9$ & $19 \cdot 7$ \\
$65-69$ & $24 \cdot 5$ & $25 \cdot 7$ \\
$70+$ & $96 \cdot 8$ & $82 \cdot 2$ \\
All ages & $11 \cdot 1$ & $7 \cdot 9$ \\
\hline
\end{tabular}

*Sample Registration System. Punjab. 1976 (combined in proportion to study population: $2 / 3$ rural, $1 / 3$ urban).

+Massachusetts Department of Public Health, 1976. membership of the Khatri or Arora castes, lack of membership of the Jath caste, use of skim milk curd, use of water low in sodium, or some combination of these factors.

Eight of the 9 positive responses to 'Sugar disease?' were in Fieldganj, and only one of the positive responses to 'Frequently urinate at night?' was in Bajakhana. Although these categories, especially the latter, are not definitively indicative of diabetes, the elevated prevalence for both categories is consistent with the known relationship between cataract and diabetes. Estimated prevalence of diabetes in this study for persons age 30 and older, based on positive response to these two questions, is $3 \%$ and is consistent with other reports on India.

Body weight, height, weight/height ratio, and frequency of use of protein foods, possible indicators of adequate nutrition, showed inverse association with cataract.

Multivariate analyses suggested that sex, economic status, use of rock salt, and Fieldganj district were unimportant in the prediction of risk of cataract when considered together with the factors in Table 7. Although age is, as expected, a strong predictor of risk, other factors also made statistically significant contributions. 'Nutrition' and weight are both significant, suggesting they singly are different or incomplete descriptions of nutritional status.

We find an association between low frequency of present use of protein foods and concurrent diagnosis of cataract. Although similar findings supported by data from nonexperimental studies in man are rare, anecdotal evidence such as given by Cass ${ }^{18}$ implicates protein and other nutritional factors. If the present nutritional level of a study individual consistently reflects the relative level over the years, so that, for example, persons nutritionally lower than average today were lower than average 10 and 20 years ago, then the association may suggest a causal relationship.

This study suggests rather broadly that low protein intake (or possibly calorie intake) is related to early development of cataract. The design does not readily permit a finer breakdown of nutrition in terms of vitamins or aminoacids. Data available on Indian and US food and protein consumption are not fully comparable owing to differences in survey intent, detail, and methodology. Nevertheless, a rough nutritional comparison of Punjab and Framingham populations suggests that an increase in Punjab consumption of protein foods to the level of US consumption would, under the multiple logistic risk function model, reduce the expected Punjab prevalence of senile cataract for ages $30+$ and $52-85$ to $9.6 \%$ and $27 \cdot 1 \%$, respectively, a $37 \%$ reduction from the observed rates. Thus perhaps $40 \%$ of the excess of Punjab cataract prevalence over Framingham shown in Table 
9 may be explained by current nutritional differences. The plausibility of a nutritional effect of this magnitude is enhanced by evidence that these 2 populations were even more nutritionally separated 10 to 20 years ago when a potential risk factor would logically have more causal impact on cataracts observed today. Still, the association of low protein consumption with increased development of cataract in man suggested here requires verification in more carefully designed studies. Especially helpful would be prospective studies or studies with stronger dietary components.

This study was supported in part by the National Society to Prevent Blindness, New York. Harold A. Kahn contributed significantly to development of the study concept and design and to early planning.

\section{References}

1 Liu HS, McGannon WJ, Tolentino FI, Schepens CL. Massive cataract relief in eye camps. Ann Ophthalmol 1977; 9: 503-8.

2 Specter A. Report on National Eye Institute cataract workshop. Invest Ophthalmol Visual Sci.1974; 13: 325-32.

3 Venkataswamy G. Massive eye relief project in India. Am J Ophthalmol 1975; 79: 135-40.

4 Chatterjee A. Mobile eye hospitals and cataract surgery in India. Israel J Med Sci 1972; 8: 1239-43.

5 Franken S. The function of a mobile eye clinic. Israel J Med Sci 1972; 8: 1243-5.

6 Franken S, Mehta KR. A Survey to Determine the Ophthalmic Morbidity in the Population Living in the Dry Belt in the Southern
Punjab and Haryana. Ludhiana, Punjab: Christian Medical College, 1968.

7 Jain IS. Blindness and Ocular Morbidity in Two Rural Blocks of Punjab and Haryana. Chandighar: Post Graduate Institute of Medical Education and Research, 1970.

8 Dhir SP, Gupta SB, Agarwal LP. Eye diseases in rural India. Orient Arch Ophthalmol 1969; 7: 85-92.

9 Chatterjee A. Cataract in Punjab. In: The Human Lens - in Relation to Cataract. Ciba Foundation Symposium 19 (new series). Amsterdam: Associated Scientific Publishers, 1973: 265-79.

10 Mehrotra SK, Maheshwari BB. Prevalence of ocular lesions in a rural community. Indian J Ophthalmol 1976; 23: 17-20.

11 Kahn HA, Leibowitz HM, Ganley JP, Kini MM, Colton T, Nickerson RJ, Dawber TR. The Framingham Eye Study. I. Outline and major prevalence findings. Am J Epidemiol 1977; 106: $17-32$.

12 Richter CP, Duke JR. Cataracts produced in rats by yoghurt. Science 1970; 168: 1372-4.

13 Hall Bowles LL, Sydenstricker VP, Schmidt HL Jr. Cataracts due to deficiency of phenylalanine, histadine and tryptophan in diets of rats. J Nutr 1948; 36: 277-95.

14 Jolly SS, Singh BM, Mather OC. Endemic fluorosis in Punjab (India). Am J Med 1969; 47: 553-63.

15 Mantel N, Haenszel W. Statistical aspects of the analysis of data from retrospective studies of disease. J Natl Cancer Inst 1959; 22: 719-48.

16 Truett J, Cornfield J, Kannel W. A multivariate analysis of the risk of coronary heart disease in Framingham. J Chron Dis 1967; 20: $511-24$.

17 Walker SH, Duncan DB. Estimation of the probability of an event as a function of several independent variables. Biometrika 1967; 54: 167-79.

18 Cass E. A decade of northern ophthalmology. Can J Ophthalmol 1973; 8: 210-7. 